\title{
A TRAMA E A URDIDURA: PERCURSOS PARA O LETRAMENTO LITERÁRIO
}

\section{THE WEFT AND THE WARP: PATHS TO LITERARY LITERACY}

\author{
Alice Atsuko Matsuda' \\ Maria de Lourdes Rossi Remenche ${ }^{2}$
}

\begin{abstract}
Resumo: $O$ processo de letramento literário constitui-se em prática privilegiada de inserçấo no mundo da escrita, pois explora a palavra por ela mesma em um processo interativo que se constrói e reconstrói continuamente. Nessa perspectiva, a formaçâo do leitor literário requer uma prática pedagógica de leitura mediada, sistematizada e planejada. Neste artigo, temos por objetivo fazer uma retomada de percursos metodológicos para o processo de ensino-aprendizagem da leitura em sala de aula, assim como partilhar uma proposta de trabalho possível para tornar a aula de Língua Portuguesa um espaço-tempo de vivência de leitura literária. Dessa forma, apresentaremos uma sequência didática para o ensino de literatura para alunos do $6^{\circ}$ ano do Ensino Fundamental, que explora o tema da relaçăo do jovem com o idoso. Essa proposta didática toma por pressuposto teórico o Método Recepcional, organizado por Bordini e Aguiar (1993), e a Sequência Básica, de Cosson (2006). Nota-se uma postura mais crítica dos alunos a cada etapa de leitura desenvolvida.
\end{abstract}

Palavras-chave: Letramento literário. Práticas de leitura. Metodologias de ensino.

Abstract: The process of literary literacy is a privileged practice of insertion in the world of writing, since it explores the word by itself in an interactive process that is continuously constructed and re-constructed. In this perspective, the development of literary readers requires a pedagogical practice of mediated, planned and systematic reading. In this article, our objective is to make a resumption of methodological paths for the teaching and learning of reading in the classroom, as well as to share a proposal on possible methodological procedures to make the Portuguese-teaching class a space and time to experience literary reading. This way, we present a didactic sequence for the teaching of literature to students in the 6th year of elementary school, which explores the theme of the relationship between young and elderly people. This didactic

1 Universidade Tecnológica Federal do Paraná-Campus Curitiba (UTFPR-Curitiba). Docente permanente do Programa de Pós-Graduaçáo em Estudos de Linguagens (PPGEL). Doutora em Letras - Estudos Literários, pela Universidade Estadual de Londrina (2009). Estágio Pós-Doutoral na Universidade de Coimbra. É líder do Grupo de Pesquisa Literatura Infantil e Juvenil: análise literária e formaçăo do leitor. E-mail: alicem@utfpr.edu.br.

2 Universidade Tecnológica Federal do Paraná-Campus Curitiba (UTFPR-Curitiba). Doutora em Linguística pela Faculdade de Filosofia e Letras da Universidade de Sáo Paulo (2009). Coordenadora do Grupo de Pesquisa em Linguística Aplicada (GRUPLA).E-mail: mlourdesrossi@hotmail.com. 
proposal takes the Recepcional Method, organized by Bordini and Aguiar (1993) and the Basic Program of Cosson (2006) as a theoretical base. It is observed at each stage of reading developed that the students have a more critical stance.

Keywords: Literary literacy. Reading practices. Teaching methodologies.

\section{INTRODUÇÃO}

A leitura é uma atividade de produçâo de sentido que aciona um processo dinâmico e complexo de interaçăo entre autor, texto e leitor. É um exercício que mobiliza aspectos sociais e cognitivos em uma imersâo em um "universo imaginário, gratuito, mas organizado, carregado de pistas as quais o leitor vai assumir o compromisso de seguir, se quiser levar sua leitura, isto é, seu jogo literário a termo" (BORDINI; AGUIAR, 1993, p. 27). Nessa concepçâo, a prática da leitura desloca o sujeito para uma posiçâo de coautor do texto, interrelacionando năo só texto e contexto do texto, mas também texto/ contexto do texto ao próprio contexto. Assim, a prática da leitura mobiliza um processo cognitivo-discursivo que sobreleva a açăo mecânica de decodificaçăo da escrita.

Nessa perspectiva, Foucambert argumenta que "ser leitor é querer saber o que se passa na cabeça de outro, para compreender melhor o que se passa na nossa" (1994, p. 30), ou seja, a leitura tem papel fundamental na formaçâo da criança como um ser dialógico, que produz sentido para os diferentes textos e contextos em que está inserida e interage.

Para Zilberman (2007), a entrada no mundo da literatura, para as crianças, as práticas de leitura fazem parte de cada etapa das experiências dos sujeitos, que vivencia, a todo momento, o universo ficcional dominado pelo imaginário. Isso ocorre porque a leitura do texto literário oferece possibilidades para que as crianças vivenciem situaçōes inusitadas, explorem a fruiçăo estética e o autoconhecimento, experienciem a literatura, promovendo a interrelaçăo entre o universo ficcional e a materialidade do texto literário, visto que "a linguagem literária pressupôe um deslocamento e, consequentemente, a provocaçáo de um estranhamento, por se estar diante de um universo singular, o universo do autor" (NUNES, 2008, p. 53).

O letramento literário na educaçấo básica demanda, por tudo isso, o desenvolvimento de projetos metodológicos que mobilize uma prática pedagógica de leitura recorrente, sistematizada a partir dos contextos, culturas e interesses das crianças, ou seja, o professor da educaçâo básica precisa assumir a funçâo de mediador de leituras literárias de forma intencional, planejada e situada. Nesse sentido, Ramos, Panozzo e Zanolla enfatizam que

[é] preciso mostrar, aos alunos, vazios, metáforas, construçăo sintática, distribuiçăo gráfica, seleçáo lexical, entre tantos outros componentes dos textos literários, para que possam se apropriar da estrutura do texto e tornem-se leitores proficientes. Acredita-se que essa abordagem contribua para a formaçăo de leitores, mas deverá ser complementada por atividades que deem conta dos demais constituintes da obra. $(2008$, p.7) 
Considerando esses aspectos, temos por objetivo, neste artigo, fazer uma breve retomada de alguns percursos metodológicos para o processo de ensino-aprendizagem da leitura em sala de aula, assim como apresentar uma proposta de prática de leitura mediada para tornar a aula de Língua Portuguesa um espaço-tempo de vivência da leitura literária. Para tanto, apresentaremos uma sequência didática para o ensino de literatura que explora o tema da relaçăo do jovem com o idoso. Essa proposta didática toma por pressuposto teórico o Método Recepcional, organizado por Bordini e Aguiar (1993), e a Sequência Básica, de Cosson (2006). Nosso percurso de retomada percorre também as ideias de Rojo (2001, 2013), Bakhtin (2004), Kleiman (2004, 2012) entre outros.

Para isso, faremos uma breve reflexăo sobre a importância do processo sistematizado de ensino-aprendizagem da leitura, exploraremos aspectos que permeiam a formaçáo do leitor para, por fim, apresentaremos o relato da aplicaçáo de um projeto para o ensino de literatura, considerando as relaçóes teórico-práticas discutidas no texto. 0 projeto foi aplicado em uma turma de $6^{\circ}$ ano de uma escola da rede pública do Paraná e teve como objetivo explorar o letramento literário das crianças envolvidas.

\title{
O PROCESSO DE ENSINO-APRENDIZAGEM DA LEITURA E ESCRITA
}

O processo de letramento envolve práticas sociais de leitura e de escrita, para além da alfabetizaçâo, pois articula, dentre outros aspectos, um conjunto de práticas sociais com as quais os sujeitos interagem em seu contexto social; nâo é apenas um conjunto de habilidades de leitura e escrita, mas também o uso dessas habilidades para interagir em diferentes situaçóes sociais. Nesse sentido, ser letrado pressupóe

\begin{abstract}
escapar da literalidade dos textos e interpretá-los, colocando-os em relaçăo com outros textos e discursos, de maneira situada na realidade social; é discutir com os textos, replicando e avaliando posiçóes e ideologias que constituem seus sentidos; é, enfim, trazer o texto para a vida e colocá-lo em relaçăo com ela. Mais que isso, as práticas de leitura na vida sáo muito variadas e dependentes do contexto, cada um deles exigindo certas capacidades leitoras e năo outras. (ROJO, 2001, p. 52)
\end{abstract}

É nesse sentido que Chartier (1998) postula a leitura como prática cultural, atividade sócio-histórica, cujo sentido se constitui nas práticas de leitura e na interaçăo do leitor com os objetos de leitura. Essa abordagem pôe em evidencia o processo de formaçấo do leitor e as lacunas e fragilidades que envolvem o letramento escolar. Chartier (1998) comenta que a leitura é uma prática encarnada em gestos, hábitos e espaços. Tal reflexăo suscita alguns questionamentos sobre as práticas de leitura que săo desenvolvidas no espaço-tempo escolar da educaçấo básica: 0 que ensinar? Quem sâo os sujeitos que estăo em nossas salas de aula? Em que contextos culturais esses sujeitos estăo inseridos? Quais concepçôes sustentam e orientam nossa prática pedagógica em sala de aula?

Para refletir sobre esses questionamentos, faz-se importante considerar que o letramento literário possui especificidades, pois constitui-se em " processo de apropriaçăo da literatura enquanto construçăo literária de sentidos" (PAULINO; COSSON, 2011, p. 67). Isso implica explorar a literatura como prática social e os textos literários, nessa concepçăo, constituem-se nos objetos por meio dos quais se efetiva o letramento, ou 
seja, faz-se necessária a vivência, a interaçăo em um constante movimento de construçâo e reconstruçăo ao longo da vida. Para Cosson, a literatura tem a funçâo de "tornar o mundo compreensível transformando a sua materialidade em palavras de cores, odores, sabores e formas intensamente humanas" (2006, p. 17).

Nessa abordagem, o processo de letramento literário constitui-se em prática privilegiada de inserçấo no mundo da escrita, pois explora a palavra por ela mesma. Esse processo năo se restringe à leitura de literatura, mas é uma prática interativa e dinâmica em que os eventos de letramento literário vâo transformando a relaçáo com a literatura ao mesmo tempo que ampliam o repertório cultural das crianças.

Considerando o espaço-tempo da sala de aula, a linguagem constitui-se em prática social, que permeia todas as relaçôes intersubjetivas, servindo de trama para as relaçôes sociais em todos os domínios. Nessa dinâmica, as palavras sáo tecidas socialmente em um constante movimento de produçăo e negociaçăo de sentido, pois as possibilidades de significaçấo săo tantas quanto os contextos possíveis (BAKHTIN, 2004). Nesse sentido, Assim, a relaçâo do sujeito com o mundo é atravessada por valores materializados nos signos, em outras palavras, é semioticamente mediada, afinal năo há um mundo que se dá a conhecer, mas versôes de mundo que săo refratadas valorativamente nos signos. Os significados, nessa concepçâo, sâo co-construídos nas interaçōes e a linguagem vai construindo, semanticamente, a realidade nas tramas das relaçóes intersubjetivas; ou seja, co-produzimos sentidos e co-construímos também nossas subjetividades nas práticas discursivas em que năo apenas produzimos linguagem, mas também somos produzidos nela. Os sujeitos se constroem, assim como constroem seus interlocutores nas várias práticas sociais em que circulam.

Tal concepçăo evidencia que, no processo de ensino-aprendizagem de leitura e escrita, precisamos sempre considerar os sujeitos, tempos, espaços de produçâo e as circunstâncias em que certo discurso foi proferido, pois "a língua, no seu uso prático, é inseparável de seu conteúdo ideológico ou relativo à vida" (2004, p. 97). Assim, toda palavra comporta duas faces, afinal a palavra proferida sempre procede de alguém, assim como se dirige para alguém, isto é, a palavra é o produto da interaçăo entre locutor e interlocutor, funcionando como uma espécie de ponte lançada entre esses sujeitos, como um território comum do locutor e do interlocutor.

Fiorin (2006) argumenta, nesse sentido, que os enunciados contêm memórias de enunciados anteriores e, entre eles, constitui-se uma relaçăo argumentativa, de refutaçăo, adesăo, pressuposiçăo, entre outras. Explicita-se, assim, que a interaçấo verbal é sempre um ato interlocutivo, responsivo e dinâmico. Isso porque năo ficamos passivos diante do que ouvimos ou produzimos. O lugar social dos sujeitos, suas experiências e as concepçōes que os constituem estăo intrincadas nos discursos. Os sentidos que produzimos entram em consonância ou em conflito com as concepçóes do outro e exigem uma resposta, uma atitude compreensiva e, ao mesmo tempo, ativa, que demonstre adesăo ou refutaçăo a uma determinada ideia.

Considerando tais aspectos, o letramento literário na dinâmica da sala de aula exige uma abordagem sistemática e metodologicamente orientada para o processo de ensino-aprendizagem da literatura, no qual o leitor assume posiçâo de sujeito ativo que constrói e é construído no texto em uma relaçăo dialógica, considerando o lugar de interaçăo e de constituiçăo dos sujeitos. 
Dando continuidade às nossas reflexóes, precisamos discutir os significados de leitura e texto literário para podermos estabelecer possíveis metodologias para o processo de ensino-aprendizagem. Na concepçâo interacionista, como dito anteriormente, o sentido năo está dado a priori, ao contrário, ele é fluido e se constrói na interaçăo texto-sujeitos. A leitura, por sua vez, é uma atividade interativa complexa de produçâo de sentidos e o texto é visto como uma unidade de sentido incompleta em que o leitor, como coautor, completará o significado. Assim, ele (leitor) e autor (produtor do texto) estarăo em diálogo contínuo.

Para Kleiman, a açâo de ler exige que o leitor mobilze uma diversidade de conhecimentos que é anterior à sittuaçâo de leitura. Os conhecimentos linguísticos, textuais e de mundo articulam-se aos conhecimentos que o texto traz e contribuem para que o leitor possa atribuir sentidos ao texto. Assim,

quanto mais conhecimento textual o leitor tiver, quanto maior a sua exposiçăo a todo tipo de texto, mais fácil será sua compreensăo, pois [...] o conhecimento das estruturas textuais e de tipos de discurso determinará, em grande medida, suas expectativas em relaçáo aos textos, expectativas estas que exercem um papel considerável na compreensăo. (KLEIMAN, 2004, p. 20)

Nessa mesma linha, a habilidade de estabelecer objetivos para a leitura é uma estratégia metacognitiva, pois definir intencionalidades contribui para apreender a coerência do texto. É uma açăo que se soma à ativaçăo dos conhecimentos prévios. Essas metas săo, na maioria das vezes, delimitadas pelo próprio texto. As estratégias de processamento do texto relacionam-se ao contexto e aos elementos linguísticos. Kleiman afirma que as categorias de significado e de contexto devem ser reconstituídas para haver compreensāo (2004, p. 47), isso implica considerar aspectos de coesâo e de coerência, além de atentar para a capacidade de refazer laços coesivos.

A leitura, considerando essas reflexôes, constitui-se em uma atividade nâo só cognitiva, mas também discursiva que possui caráter multifacetado e multidimensional. É um ato social entre dois sujeitos - leitor e autor - que interagem em um processo complexo que envolve percepçâo, processamento, memória, inferência, deduçăo, induçăo, ou seja, é um processo em que o leitor atua participativamente, buscando recuperar, interpretar e compreender os sentidos e as intençôes pretendidas pelo autor.

Para isso, o leitor utiliza diversas estratégias baseadas no seu conhecimento, considerando o contexto linguístico e extralinguístico de produçâo e circulaçăo do texto. Na prática leitora, inúmeros processos sâo acionados simultaneamente e os sentidos produzidos estâo também relacionados aos objetivos do leitor. Assim, à proporçáo que o texto vai sendo lido, o leitor vai elaborando e testando hipóteses sobre o sentido. Vai também ativando seu conhecimento de mundo e esquemas que contribuem, durante a leitura, para a elaboraçăo de inferências a partir de marcas formais do texto.

Nesse contexto dialógico, o sujeito está inserido em formaçôes discursivas que sâo determinadas sócio-historicamente, e ambos, sujeito e sentido, văo se constituindo reciprocamente. Assim, no processo de compreensăo, acionamos outros discursos, interagimos com outras vozes, retomamos outros textos, mobilizamos diferentes posiçóes ideológicas, entre outros. 


\section{Bordini e Aguiar corroboram com essas ideias ao argumentarem que}

[numa] sociedade desigual, os problemas de leitura se diversificam conforme as características de classe. As soluçóes possíveis se orientam para o pluralismo cultural, ou seja, a oferta de textos vários, que deem contam das diferentes representaçóes sociais. Se as classes trabalhadoras também tiverem acesso à alfabetizaçâo, serăo elas năo apenas consumidoras passivas, mas produtoras de novos textos, que se acrescentarăo aos que circulam na sociedade e atenderăo a seus interesses. (1993, p. 13)

As autoras argumentam ainda que

Todos os livros favorecem a descoberta de sentidos, mas săo os literários que o fazem de modo mais abrangente. Enquanto os textos informativos atêm-se aos fatos particulares, a literatura dá conta da totalidade do real, pois, representando o particular, logra atingir uma significaçáo mais ampla. (1993, p. 13)

Assim, além de ler textos informativos, instrucionais, científicos, acadêmicos, as crianças, desde os anos iniciais da escolarizaçâo, precisam ter acesso aos textos literários, responsáveis por promover a fruiçăo e o sensível, o diálogo com outras formas de representaçáo de mundo, entre outros. A literatura propicia um encontro singular com a linguagem que potencializa nossa capacidade de criar, recriar e vivenciar o mundo e a nós mesmos. Nesse sentido, Bordini e Aguiar afirmam que o texto literário é mais completo, pois, além de possibilitar o conhecimento do mundo e de si mesmo, propicia o prazer, a humanizaçăo.

Nessa perspectiva, "o texto literário é um labirinto de muitas entradas, cuja saída precisa ser construída uma vez e sempre pela leitura dele" (COSSON, 2006, p. 65). Portanto, pelo fato de no texto literário prevalecer a ambiguidade e a plurissignificaçấo, necessita-se de um leitor participativo, visto que no momento do encontro da obra com o leitor, este terá que ativar o seu conhecimento de mundo e produzir os sentidos do texto, interpretando e preenchendo os espaços lacunares deixadas pelo autor. Para Bordini e Aguiar,

[a] obra literária pode ser entendida como uma tomada de consciência do mundo concreto que se caracteriza pelo sentido humano dado a esse mundo pelo autor. Assim, náo é um mero reflexo na mente que se traduz em palavras, mas o resultado de uma interaçăo ao mesmo tempo receptiva e criadora. Essa interaçăo se processa através da mediaçăo da linguagem verbal, escrita ou falada. 0 texto produzido, graças a essa natureza verbal, permite o estabelecimento de trocas comunicativas dentro dos grupos sociais, pondo em circulaçăo esse sentido humano. (1993, p. 14)

Essas consideraçôes suscitam reflexôes acerca da importância da intencionalidade pedagógica para sistematizar os processos de leitura em sala de aula, fundamentados em metodologias adequadas à faixa etária e ao contexto dos alunos. Para ampliarmos essa discussáo, retomaremos alguns aspectos que envolvem a formaçăo do leitor.

\section{O PROCESSO DE FORMAÇÃO DO LEITOR}

Cosson (2011) argumenta que a leitura, como construçăo de sentidos, está no centro do letramento literário e implica a leitura do texto, do contexto e do intertexto da 
obra. É dessa leitura que se obtém a experiência literária. Considerando essa dinâmica, pode-se afirmar que "é possível ensinar a ler na escola, quando ambos, professor e aluno, se movimentam no debruçar sobre os textos a partir de um processo de interaçăo" (LEAL, 1999, p. 267). Para tanto, é preciso levar em consideraçăo o sujeito leitor, o aluno-sujeito cognitivo, que detém um saber, um conhecimento, uma experiência que devem ser respeitados. Além disso, esse sujeito possui valores construídos no contexto sociocultural e é capaz de refletir, relacionando o conhecimento adquirido e os valores que possui. Esse trabalho pedagógico com o texto literário explora, de maneira dinâmica, aspectos que văo do simples para o complexo, do próximo para o distante no tempo e no espaço para ampliar o horizonte de expectativa do leitor.

Isto significa optar, primeiramente, por textos conhecidos de autores atuais, familiares pela temática apresentada, pelos personagens delineados, pelos problemas levantados, pelas soluçōes propostas, pela forma comose estruturam, pela linguagem de que se valem. A seguir, gradativamente, váo-se propondo novas obras, menos conhecidas, de autores contemporâneos e/ ou do passado, que introduzam inovaçóes em alguns dos aspectos citados. Estes procedimentos, inusitados para o leitor, rompem sua acomodaçăo e exigem uma postura de aceitaçăo ou descrédito, fundada na reflexăo crítica, o que promove a expansăo de suas vivências culturais e existenciais. (BORDINI; AGUIAR, 1993, p. 25)

As alternativas metodológicas, propostas por Bordini e Aguiar (1993), exploram cinco metodologias de ensino de literatura, com fundamentaçâo teórica, objetivos e critérios de avaliaçăo, explicaçăo das etapas de desenvolvimento de cada metodologia, além de três exemplos que foram aplicados e testados nas salas de aula de alunos do primeiro e do segundo ciclos do Ensino Fundamental e do Ensino Médio. As autoras sugerem o trabalho com o texto literário, por meio do Método Científico, Método Criativo, Método Recepcional, Método Comunicacional e Método Semiológico.

Dentre as metodologias apresentadas pelas autoras, o Método Recepcional ${ }^{3}$ tem produzido bons resultados para a formaçăo do leitor competente ao ser aplicado sistematicamente por um longo período. Esse método de ensino de literatura enfatiza a comparaçăo entre o familiar e o novo, entre o próximo e o distante no tempo e no espaço. Além disso, o processo de trabalho apoia-se no debate constante, em todas as formas: oral e escrito, consigo mesmo, com os colegas, com o professor e com os membros da comunidade. Portanto, o método é eminentemente social ao pensar o sujeito em constante interaçấo com os demais por meio do debate, e ao atentar para a atuaçáo do aluno como sujeito da História.

Assim, as autoras sugerem cinco etapas a serem desenvolvidas. Inicialmente, busca-se delimitar o horizonte de expectativas, por meio de açôes didáticas que envolvem rodas de conversa, troca de experiências de leitura e dinâmicas de investigaçấo sobre o conhecimento prévio dos alunos, a fim de prever estratégias de ruptura e transformaçâo desse horizonte. Em seguida, desenvolvem-se estratégias para se atender a

3 A base teórica do método é a Teoria da Estética da Recepçăo (JAUSS, 1994) que tem como foco o leitor. Verifica-se que as sete teses da teoria estáo imbricadas na organizaçáo do Método Recepcional, principalmente, no que concerne à "distância estética" - a diferença entre as expectativas e a forma concreta de uma obra nova. "A distância entre o horizonte de expectativa e a obra, entre o já conhecido da experiência estética anterior e a 'mudança de horizonte' exigida pela acolhida à nova obra, determina, do ponto de vista da estética da recepçăo, o caráter artístico de uma obra literária" (JAUSS, 1994, p.31). 
esse horizonte de expectativas, por meio de experiências com textos literários que satisfaçam as necessidades dos alunos quanto ao objeto escolhido e às estratégias de ensino. A etapa da ruptura do horizonte de expectativas constitui-se pela introduçáo de textos e atividades de leitura que irăo abalar as certezas e os costumes dos alunos, seja em termos de literatura ou de vivência cultural. Na sequência, abre-se espaço para o questionamento do horizonte de expectativas por meio da comparaçăo entre os dois momentos anteriores, verificando que conhecimentos escolares ou vivências pessoais, em qualquer nível, proporcionarăo a eles facilidade de entendimento do texto e/ou abrirăo-lhes caminhos para atacar os problemas encontrados. Essa é uma dinâmica metacognitiva importante para a constituição do leitor. Por fim, na ampliaçáo do horizonte de expectativas, os alunos tomarâo consciência das alteraçôes e aquisiçôes, obtidas por meio da experiência com a literatura. Conscientes de suas novas possibilidades de manejo com a literatura, partem para a busca de novos textos, que atendam a suas expectativas ampliadas no tocante a temas e composiçăo mais complexos.

No final da última etapa, inicia-se uma nova aplicaçăo do método, que evolui em espiral, sempre permitindo aos alunos uma postura mais consciente em relaçâo à literatura e à vida. Portanto, tendo como base a teoria da Estética da Recepçấo (JAUSS, 1994), e seguindo a metodologia proposta por Bordini e Aguiar (1993) - Método Recepcional -, acreditamos que tal sistematizaçăo contribua para a formaçăo de um leitor crítico, que tem competência para ler e compreender uma obra esteticamente elaborada, seja de seu momento histórico, seja de períodos passados, visto que é uma proposta de ensino de leitura da literatura como um processo gradativo de crescimento intelectual e cultural do leitor, ao longo de sua escolarizaçâo.

Com o intuito de gerar um processo metodológico, Cosson (2006) sistematiza as atividades das aulas de literatura em duas sequências exemplares: Sequência Básica - voltada mais para o Ensino Fundamental - e a Sequência Expandida - voltada para - Ensino Médio. O objetivo do autor é "apresentar duas possibilidades concretas de organizaçăo das estratégias a serem empregadas nas aulas de Literatura" (2006, p. 48). Essas propostas ilustram possibilidades para sistematizar o ensino da literatura, embora năo sejam modelos que devam ser seguidos sem questionamento ou adaptaçăo, pois o mediador, em sua práxis, precisa atuar de acordo com a realidade de cada escola e dos alunos de cada sala de aula. As sequências têm base nas três perspectivas metodológicas: a técnica da oficina, a técnica do andaime e a técnica do portfólio.

Cosson sugere, ainda, que o professor faça o acompanhamento da leitura do texto literário, quando se solicita a leitura de uma obra. Segundo ele, năo basta apenas pedir para ler determinada obra, mas há necessidade de dialogar com o aluno sobre a leitura que está sendo realizada, além de motivá-lo para que tenha interesse em ler. Após a motivaçáo realizada para despertar o interesse do aluno pela leitura e suscitar a curiosidade, o professor pode dividir em vários intervalos a leitura da obra, conforme a necessidade e o assunto ou tema abordado. A cada intervalo, propiciar uma conversa sobre a leitura feita e trazer outros textos para dialogar com a obra lida. Assim, o leitor vai ampliando seu conhecimento, relacionando a leitura da obra com outros textos e com sua experiência de vida, socializando sua aprendizagem na discussăo em sala com os colegas e o professor. 
Ao final da leitura, Cosson indica também a realizaçăo de uma produçâo escrita, como forma de registro. Essas possibilidades metodológicas evidenciam a possibilidade de aliar o ensino de língua e literatura. Nessa perspectiva, o Método Recepcional possibilita ao professor planejar seu trabalho anual em que poderá aplicar as cinco etapas do método em um bimestre ou trimestre, de acordo com o planejamento curricular de sua escola, dando continuidade de forma espiral, levando o aluno a uma postura mais crítica diante do texto. Na etapa da ampliaçâo do horizonte de expectativa, momento em que geralmente é oferecida ao aluno a leitura de uma obra literária de maior fôlego, o professor poderá aplicar a Sequência Básica ou Expandida sugerida por Cosson para um trabalho mais pontual com a leitura da obra literária. Na fase do registro, conforme já mencionado, pode-se aplicar outros momentos das etapas do Método Recepcional, ampliando o trabalho com a oralidade, produçâo escrita e análise linguística.

Por meio desses percursos metodológicos, verifica-se que, para desenvolver a capacidade leitora do alunado, o professor precisará assumir o papel de mediador, interagindo com o aluno e com o texto, reforçando a importância de seu lugar social como docente e como leitor mais experiente que articula os processos interativos que envolvem a formaçăo do leitor, visto que todo e qualquer conhecimento é perpassado pela linguagem e, só e por meio dela, poderá ser organizado e acessado. Apenas assim poderemos superar práticas de letramento escolar etnocentradas e monoculturais.

\section{ESTABELECENDO RELAÇÕES TEÓRICO-PRÁTICAS: UM EXEMPLO}

Considerando os aspectos teóricos discutidos até aqui, foi desenvolvido um projeto de ensino de literatura, com foco no letramento literário. Para tanto, foi desenvolvida uma sequência didática para dois meses de trabalho com o objetivo de verificar a eficácia do uso do Método Recepcional aliada à Sequência Básica, possibilitando trabalhar a partir do texto literário o ensino de literatura e de língua portuguesa. Dessa forma, buscou-se contribuir para a formaçăo de um leitor mais competente, além de cumprir com os objetivos do ensino de Língua Portuguesa por meio da leitura, oralidade, produçâo e análise linguística. No entanto, há de ressaltar que apenas com a aplicaçăo de um bimestre dessa sequência didática năo há como alcançar o objetivo proposto. Pois, para formar um leitor competente, há a necessidade da aplicaçăo sistemática e recorrente dessas práticas durante toda a educaçăo básica. Contudo, há de se observar também que, a cada etapa de aplicaçâo do método, o estudante vai se tornando um aluno mais perspicaz no entendimento do texto, preenchendo os vazios, levantando hipóteses, estabelecendo mais relaçóes e respondendo aos questionamentos que o texto solicita. Para o desenvolvimento do projeto, optou-se por uma metodologia de estudo de caso aplicado em um $6^{\circ}$ ano do Ensino Fundamental, de uma escola pública estadual da regiâo norte do Paraná. A turma era composta de 35 alunos, com maioria de meninas: 23 meninas e 12 meninos. A escola possui um porte médio, com 15 turmas e uma média de 245 alunos. Localizada em um distrito, próximo à zona rural, os alunos, em sua maioria, săo filhos de agricultores ou funcionários de uma empresa têxtil, com perfil econômico médio. Todos moram com os pais ou avós e o contato com o livro, em sua maioria, é na escola. Esses dados do perfil do aluno foram colhidos por meio da aplicaçâo de um questionário que teve por objetivo o diagnóstico do contexto cultural dos alunos. O projeto foi aplicado pela professora de Língua Portuguesa da turma que possui mestrado na 
área de Literatura e Ensino. A professora, em sua prática pedagógica, explorou teorias metodológicas em que o professor tem papel de mediador da leitura, motivando os alunos a perceber os vazios do texto e preenchê-los adequadamente, conforme as possibilidades de sentido. Além disso, a professora buscou fazer com que os alunos compreendessem a construçấo do texto, a literariedade no uso da linguagem. Todo o desenvolvimento do projeto foi permeado por atividades avaliativas que percorreram a funçăo diagnóstica e formativa. A partir das informaçóes coletadas nesse processo, a prática pedagógica foi sendo regulada para atender às diferentes aprendizagens. Para o desenvolvimento da prática de leitura, foram utilizados os livros Guilherme Augusto Araújo Fernandes (1996), de Men Fox, Bisa Bia, Bisa Bel(1999), de Ana Maria Machado e 0 olho de vidro do meu avô (2000), de Bartolomeu Campos de Queirós. Além disso, a base metodológica teve como pressupostos teóricos o Método Recepcional, organizado por Bordini e Aguiar (1993) e a Sequência Básica proposta por Cosson (2006).

Inicialmente, a professora fez a discussăo, com os alunos, sobre a definiçăo de memória. Para isso, realizou uma dinâmica a fim de fazer com que os alunos refletissem sobre a concepçáo de memória. Foram confeccionadas tiras de papéis com conceitos de memória. Esse material foi colocado em uma caixinha para que cada aluno fosse retirando um papel. Em seguida, a professora organizou uma espécie de caracol com linha de lá no centro da sala e pediu para que os alunos colocassem no centro do caracol o que eles achavam que definisse, de forma objetiva, o que era memória; na continuaçăo do caracol, o que năo definisse com clareza e, na última parte do caracol, o que năo remetesse ao sentido do termo memória. Além disso, a docente pediu para que os estudantes justificassem a própria opiniâo sobre o conceito em estudo.

Depois que todos colocaram os papéis com as definiçóes, a professora problematizou as definiçóes apresentadas, questionando se alguém năo concordava com a opiniấo de algum colega, se achava que alguma definiçăo deveria ser deslocada de lugar. Essa dinâmica suscitou discussóes e reflexóes e possibilitou aos alunos perceberem que as pessoas têm opiniôes diferentes devido à própria experiência de vida e de leitura. Tal reflexăo contribuiu para a ampliaçâo do conceito de memória.

Essa etapa, constitui-se na determinaçăo do horizonte de expectativas, em que se pôde conhecer o interesse e o pensamento dos alunos sobre o tema, fator determinante para o sucesso do trabalho com o Método Recepcional.

Assim, após essa dinâmica, a professora convidou os alunos a ler o livro Guilherme Augusto Araújo Fernandes. De acordo com a sugestăo de Cosson, ao trabalhar com a obra literária, para criar o interesse pela leitura, como motivaçăo, pode-se questionar por que o livro tem esse título, de que irá tratar, enfim, criar suposiçôes ativando a curiosidade do aluno. Nessa concepçăo, a docente motivou os alunos ao problematizar o título da obra e levantar possibilidades de sentido que poderiam ou năo ser confirmadas ao longo da leitura da obra. Atendendo às orientaçóes de Cosson, ela introduziu a leitura do livro, apresentando a autora e explicando que o livro traz uma definiçấo de memória interessante, e se eles náo gostariam de saber. Para Cosson, o momento da "motivaçăo" como da "introduçăo", embora pareça ser uma atividade simples, necessita de cuidados do professor, para que năo se torne uma aula expositiva enfadonha sobre a vida do autor ou que apenas se realize o resumo do enredo da obra. Para isso, faz-se necessário apresentar dados tanto do autor, quanto da obra. 
Men Fox, além de ser uma escritora australiana de livros infantis, é também educadora especializada em alfabetizaçăo. Já recebeu vários prêmios por seus livros, como o selo Altamente Recomendável pela Fundaçăo Nacional do Livro Infantil e Juvenil - FNLIJ e, hoje, vive na cidade de Adelaide, na Austrália, longe de uma rotina agitada. O livro trata da história de Guilherme Augusto, um garoto que mora ao lado de um asilo e tem uma grande amizade com todos os idosos de lá, especialmente, uma senhora chamada Dona Antonia. Certo dia, o menino ouve seus pais comentarem que a sua amiga preferida havia perdido a memória. Intrigado com essa informaçăo, pergunta aos seus pais o significado de memória. Insatisfeito ainda com a resposta, indaga também a todos os idosos do asilo sobre o significado dessa palavra.

Depois de obter essa informaçấo, ele sai em busca de objetos que, para ele, concretizam as diferentes respostas. Reúne-os em um cesto e leva-os de presente para sua amiga que, ao tocá-los, lembra-se de alguns momentos significativos de sua infância: cada objeto lhe devolve a lembrança de belas histórias. Guilherme Augusto parte de uma informaçăo subjetiva de memória e, de forma lúdica, constrói o significado de maneira concreta.

Esse é um texto que privilegia o ponto de vista da criança que brinca, investiga, dialoga e vai construindo sua forma de se posicionar frente ao universo do adulto, de maneira simples, desconstruindo toda visăo complexa que o adulto possui quanto à perda de memória do idoso. Na simplicidade, por meio da personagem Guilherme, verifica-se que o adulto, muitas vezes, tem uma concepçăo complexa diante da doença; já a criança possui uma visâo simples e de fácil soluçâo.

A leitura da obra foi feita de forma coletiva, visto que é uma obra de poucas páginas e com muitas ilustraçôes. No trabalho de mediaçâo da leitura, a professora foi estabelecendo relaçóes entre a linguagem verbal e nâo-verbal do livro e as possibilidades de sentido. Em seguida, com a mediaçâo da professora, a turma foi analisando a obra e levantando possibilidades de significar o texto. Nessa discussâo, a professora observou que os alunos compreenderam bem o sentido global do texto, além de conseguirem perceber o significado de memória presente no livro: algo quente, algo antigo, algo que vale ouro, algo que faz rir, algo que faz chorar.

Assim, a professora retomou a dinâmica anterior em que essas definiçôes estavam presentes e que poderiam suscitar dúvidas em relaçăo à definiçăo de memória. Pelo fato de essas definiçôes estarem agora contextualizadas na história, ganharam outro significado. Dessa forma, os alunos perceberam a complexidade do texto e do tema abordado, de forma lúdica e criativa.

No trabalho de estabelecimento de relaçôes entre a linguagem verbal e nâo-verbal, foram também analisadas as ilustraçōes, a disposiçâo das imagens que valorizam o texto, os tons claros que reproduzem a distância entre a criança e o idoso, criando uma aproximaçăo pelo diálogo que os desenhos estabelecem entre si. Nessa análise, a professora direcionou o olhar das crianças para o jogo de transparências das cores, que simbolizava a memória perdida, mas nâo apagada da dona Antônia.

Depois dessas etapas de "leitura" e de "interpretaçâo", a docente solicitou aos alunos que trouxessem objetos que lembrassem o próprio passado, a infância de cada um. Nessa obra, pelo fato de ser um livro de pouca extensăo, năo houve necessidade dos "intervalos" previstos na Sequência Básica de Cosson, pois, após a leitura coletiva, 
o professor foi mediando a análise interpretativa da obra e auxiliando quaisquer dificuldades dos alunos.

Na aula seguinte, cada aluno fez um breve relato da história dos objetos que trouxe, o que eles representavam e como poderiam ser relacionados à história lida. Essa etapa foi a do "registro" sugerido por Cosson, em que por meio desse exercício, o professor desenvolve atividades de interpretaçâo da obra lida, servindo também como avaliaçăo do processo de leitura. No Método Recepcional, com a leitura do livro Guilherme Augusto Araújo Fernandes atendeu-se ao horizonte de expectativas dos alunos.

Depois de atender à expectativa dos alunos, chegou o momento de romper com o que se é esperado a fim de ampliar a capacidade crítico-compreensiva na formaçâo do leitor. Esse é o momento de efetuar a transiçăo para uma literatura de ordem mais exigente. Para isso, a professora propôs a leitura do livro Bisa Bia, bisa Bel, de Ana Maria Machado, que narra a história de três geraçôes: Bisa Bia representa o passado; Isabel representa o presente e Neta Beta representa o futuro. Isabel, por meio do convívio imaginário com sua bisavó (Bisa Bia) e sua bisneta (Neta Beta) aprende a conviver consigo mesma, a se relacionar com outras pessoas e descobre um mundo onde a fantasia e a realidade se misturam, trazendo encantos, desencontros, travessuras, medo e muito amor.

Bisa Bia é a figura experiente que transmite conhecimentos. No entanto, seus valores entram em choque com os valores de Isabel e de Neta Beta. O encontro das três geraçōes provoca descobertas de novos valores, reavaliaçôes de conceitos antigos e mudanças de comportamento.

Como em Guilherme Augusto Araújo Fernandes, optou-se pelo emprego da Sequência Básica proposta por Cosson para trabalhar com a obra Bisa Bia, Bisa Bel. Portanto, para motivar a leitura do livro, conforme o estudioso, houve um momento de questionamentos sobre o título do livro, e o levantamento de hipóteses sobre o tema e o enredo da obra, enfim, ativou-se a curiosidade dos alunos. Segundo Cosson (2006), o que náo pode acontecer é o professor tentar conduzir a leitura literária, empobrecendo o texto ou cerceando a interpretaçấo do aluno.

Na etapa da "introduçâo", primeiramente, a professora perguntou se alguém já conhecia a autora Ana Maria Machado, se já havia lido alguma obra dela. Dos 35 alunos, apenas três já haviam lido outra obra da autora. Em virtude disso, foi realizada a apresentaçâo da autora, assim como a apresentaçáo física da obra, chamando atençáo para "a leitura da capa, da orelha e de outros elementos paratextuais que introduzem a obra" (COSSON, 2006, p. 60). Em seguida, iniciou-se uma roda de conversa sobre as relaçóes de amizade com as avós/bisavós ou seu avôs/bisavôs. A maioria das crianças relatou a presença dessa amizade, inclusive, dois alunos relataram que eram cuidados pelos avós.

Depois dessa conversa, a professora iniciou a motivaçăo para a leitura do livro, perguntando se essa história poderia tratar da relaçăo entre neta e a bisavó, visto que no título "Bisa" poderia significar bisavó. Uma aluna respondeu que poderia ser uma história de duas bisavós: Bisa Bia e Bisa Bel. Esse foi o mote para criar a curiosidade e iniciar a leitura da obra, motivados a conhecer uma história em que uma garota mantém um diálogo com sua bisavó e descobre muitas coisas interessantes.

A leitura do livro foi iniciada na sala, coletivamente, lendo um capítulo e discutindo as ideias principais. Como náo havia livros suficientes para todos, apenas 15 
exemplares, o professor entregou para que 15 alunos fossem lendo o livro durante a semana, extraclasse, e depois fossem passando para os outros colegas, assim que terminassem de ler, até que todos da sala tivessem oportunidade de ler a obra toda. Enquanto todos os alunos fossem fazendo a leitura extraclasse de Bisa Bia, Bisa Bel, o professor foi trazendo outros textos que pudessem complementar o entendimento da leitura da obra e/ou ampliar. Para Cosson, nessa etapa, é muito importante que haja o acompanhamento da leitura pelo professor para que a proposta de letramento literário seja eficaz, pois

A leitura escolar precisa de acompanhamento porque tem uma direçăo, um objetivo a cumprir, e esse objetivo náo deve ser perdido de vista. Náo se pode confundir, contudo, acompanhamento com policiamento. 0 professor năo deve vigiar o aluno para saber se ele está lendo o livro, mas sim acompanhar o processo de leitura para auxiliá-lo em suas dificuldades, inclusive aquelas relativas ao ritmo da leitura. (2006, p. 62)

Năo importa se há alguns alunos que săo mais rápidos e outros mais vagarosos na leitura do livro, pois o que importa "é a experiência estética que ele proporciona e náo simplesmente a história que conta" (COSSON, 2006, p. 63). Nessa perspectiva, a professora foi chamando a atençâo dos alunos para que eles percebessem a maneira como a autora tratou determinados assuntos, a linguagem empregada e a forma como o texto foi escrito, o trabalho enunciativo do artista.

Nas discussōes, privilegiou-se a reflexăo sobre os valores de namoro, casamento, comportamento de menina e de menino, questôes debatidas entre Bisa Bia, Isabel e Neta Beta na obra. A professora, nas discussôes, procurou fazer com que os alunos percebessem como Ana Maria Machado escreveu sobre esses assuntos, de que forma a autora trouxe à tona esses temas, enfim, o recurso literário empregado pela escritora.

Analisar o trabalho literário da construçăo do texto pela autora é primordial, para que os alunos percebessem e vivenciassem essa experiência estética da elaboraçâo do texto. O mecanismo de como Ana Maria Machado desenvolveu o texto, por via do imaginário, em que três geraçôes se encontram e os valores entram em choque, foi debatido, comparando com os valores de hoje, dos próprios alunos. Esse momento propiciou também discutir a relaçăo deles com as suas avós e seus avôs. Além disso, favoreceu, por parte dos estudantes, a ampliaçáo do repertório cultural ao se tratar de objetos utilizados e dos alimentos de antigamente, que săo acionados na narrativa das histórias e das experiências de vida de Bisa Bia.

Finalizada essa etapa, o próximo momento é o do questionamento do horizonte de expectativa. Essa fase destinou-se à reflexăo sobre o tema, com levantamento de novos dados que auxiliam a compreensâo do texto. Assim, a professora retomou a história do primeiro livro, Guilherme Augusto Araújo Fernandes, como de Bisa Bia, Bisa Bel, em que a criança tem um relacionamento de amizade com os idosos e um diálogo profícuo. Essa retomada motivou os alunos a vivenciar isso também com suas avós e seus avôs.

Dessa forma, sugeriu-se aos alunos visitarem seus avós para conversarem sobre a época de criança e de juventude deles. Caso algum aluno tivesse dificuldade para realizar essa atividade, eles poderiam fazer uma visita a um senhor ou a uma senhora de mais de 60 anos (vizinhos, amigos ou realizar uma visita a asilos, por exemplo). 
Nesse momento também foram exploradas atividades de produçâo de texto, pois os alunos foram orientados a realizar uma entrevista com suas avós/avôs. Para isso, a professora explorou o gênero textual, trouxe modelos de entrevistas e explicou a estrutura composicional, a linguagem empregada, o estilo da escrita, os recursos linguísticos utilizados. Em seguida, construiu, juntamente com os alunos um roteiro de entrevista em que havia perguntas mais pessoais para que os alunos pudessem elaborar a apresentaçăo do entrevistado e perguntas mais gerais, relacionadas à obra lida, como: 1) Como era o tempo de criança na época do senhor(a)? 2) Quais eram as brincadeiras? 3) O comportamento de menino e de menina era muito diferente? 4) Menina podia usar calça comprida e/ou shorts? 5) Como era a roupa de menino e de menina? 6) Como era o estudo, a escola, os professores, o relacionamento dos alunos com seus colegas e professores? 7) Utilizavam-se de algum objeto, meios de transportes, alimentos que hoje já nâo săo mais comuns? 8) Como as pessoas se comunicavam?

Depois, em data previamente marcada, os alunos apresentaram os resultados de sua conversa com suas avós e/ou avôs. Essa atividade possibilitou relacionar as histórias dos dois livros lidos anteriormente com a entrevista realizada. Além disso, favoreceu a interaçâo dos estudantes com suas avós e/ou seus avôs, ampliando a relaçăo de amizade, além de valorizar o conhecimento dos idosos.

A última etapa, ampliaçăo do horizonte de expectativas, constitui-se no ápice do trabalho, pois depois romper o horizonte de expectativas, a docente buscou ampliar a visâo e o conhecimento sobre o tema do projeto. Para isso, foi realizada a indicaçăo da leitura do livro 0 Olho de vidro do meu avô (2000), de Bartolomeu Campos de Queirós. Seguindo a sugestâo de Cosson para motivar a leitura, houve um momento inicial de conversa com os alunos e o questionamento se alguém da turma conhecia ou mesmo já viu alguém que tivesse olho de vidro.

A partir dessa discussâo, introduziu-se a obra, explorando o título, trabalhando a capa do livro, apresentando o autor. A leitura do livro foi iniciada em sala com discussôes das ideias principais e da construçâo poética do texto. Além disso, os alunos realizaram leituras individuais extraclasse, da mesma forma como foi feito com a leitura de Bisa Bia, Bisa Bel.

Nesse livro também, os alunos tiveram a oportunidade de percorrer os labirintos da memória, principalmente, a memória da infância. Bartolomeu recria a infância com a poética das palavras: os sentimentos vividos, os episódios cuidadosamente guardados se extravasam em uma linguagem permeada de musicalidade e silêncio que rompe as fronteiras do tempo.

Para encerrar esta etapa do projeto de leitura, conforme sugestăo de Cosson, foi realizado o registro da atividade e um café comunitário com a presença dos avós e alguns idosos da comunidade. Além disso, os alunos fizeram apresentaçăo de dança, contaram as histórias dos livros lidos, dramatizaram algumas cenas da obra. Esse evento constituiu-se em uma oportunidade de promoçáo do diálogo entre as crianças e os idosos. A comunicaçăo intergeracional possibilitou aos idosos e às crianças à compreensâo de que a dinâmica das geraçóes promove intercâmbios positivos.

A proposta do Método Recepcional é que, ao final das cinco etapas, inicie-se "uma nova aplicaçâo, que evolui em espiral, sempre permitindo aos alunos uma postura mais consciente com relaçâo à literatura e à vida" (BORDINI; AGUIAR, 1993, p. 91). Dessa 
forma, o professor, juntamente com os alunos conscientes de suas novas possibilidades de manejar o texto literário, pode escolher outras obras que podem atender às expectativas ampliadas em termos de temas e composiçấo mais complexos, dando continuidade ao projeto de formaçăo de leitor.

\section{CONSIDERAÇÕES FINAIS}

Paulo Freire (1985) argumenta que "a leitura do mundo precede a leitura da palavra, daí que a posterior leitura desta náo possa prescindir da continuidade da leitura daquela. Linguagem e realidade se prendem dinamicamente" (p. 11-12). Nessa concepçâo, a leitura implica a capacidade de ler o mundo, significando-o, assim como a nós próprios. Nessa perspectiva, a prática docente năo envolve apenas o processo de ensino da leitura, mas também a criaçáo de condiçōes para que o aluno possa construir a própria aprendizagem, conforme seus próprios interesses, necessidades, fantasias, considerando as dúvidas e exigências que a realidade lhe apresenta.

As reflexōes e possibilidades metodológicas apresentadas neste artigo enfatizam a importância de uma teoria e de uma metodologia que norteiem o trabalho de formaçáo do leitor. No projeto relatado, verifica-se que, para desenvolver um projeto de leitura, a Teoria da Estética da Recepçáo e o Método Recepcional auxiliaram na organizaçấo e seleçấo dos textos para alcançar o objetivo de transformar sócio e culturalmente o leitor, capacitando-o a descobrir sentidos na leitura e a reelaborar aquilo que ele é e o que poderá ser, tendo uma postura crítica ante o mundo e a práxis social. A Sequência Básica sugerida por Cosson (2006) proporciona uma sistematizaçăo para que o professor faça uma leitura da obra literária, aprofundando a análise interpretativa e ampliando o horizonte de expectativa do aluno.

Segundo Bordini e Aguiar, a "adoçăo de um método pedagógico supōe que se optou por uma linha filosófica de educaçáo. Essa escolha determina todo o processo de ensino-aprendizagem, orientando-o para um certo tipo de aluno que se prevê formar" (1993, p.152). O Método Recepcional, por exemplo, objetiva formar alunos que năo temem a ruptura com o estabelecido, alunos questionadores e flexíveis em termos de ajustamentos sociais e que sejam capazes de ler, a cada ciclo trabalhado, textos mais complexos.

Com isso, pode-se perceber que os alunos, em cada etapa trabalhada, têm a chance de se tornarem mais críticos e perspicazes nas inferências do texto, pois se proporciona a ampliaçấo de seu repertório cultural. O método faz com que o aluno nâo fique apenas na leitura superficial, afetiva, presa ao enredo, mas estimula-os a estabelecer relaçôes e elaborar inferências, ressignificando o texto.

Além disso, nota-se a importância de escolher bem os textos a serem trabalhados para envolver o leitor que ainda nâo formou o gosto pela leitura literária, além de possibilitar que ele viaje no mundo imaginário, fantástico e prazeroso.

No final da etapa do projeto, ao compartilhar as leituras e apresentar seu ponto de vista, aceitando ou refutando ideias, os alunos exercitam a interaçăo entre si, entre eles e o professor, entre os alunos, o texto e o autor, ocasionando um alargamento da visăo de mundo e do próprio horizonte. 


\section{REFERÊNCIAS}

BAKHTIN, Mikhail (Volochinov). Marxismo e filosofia da linguagem. Săo Paulo: Hucitec, 2004.

BORDINI, Maria da Glória; AGUIAR, Vera Teixeira. Literatura: a formaçăo do leitor: alternativas metodológicas. Porto Alegre: Mercado Aberto, 1993.

CHARTIER, Roger. A aventura do livro: do leitor ao navegador. Traduçâo Reginaldo de Moraes. Săo Paulo: Imprensa Oficial do Estado de Sáo Paulo; Edunesp, 1998.

COSSON, Rildo. Letramento literário: teoria e prática. Săo Paulo: Contexto, 2006.

FIORIN, José Luiz. Introduçāo ao pensamento de Bakhtin. Săo Paulo: Ática, 2006.

FOUCAMBERT, Jean. A leitura em questâo. Traduçăo B. C. Magne. Porto Alegre: Artes Médicas, 1994.

FOX, Mem. Guilherme Augusto Araújo Fernandes. Traduçăo de Gilda de Aquino e ilustraçâo de Julie Vivas. Sâo Paulo: Brinque-Book, 1996.

FREIRE, Paulo. A importância do ato de ler em três artigos que se completam. Sáo Paulo: Cortez, 1985

GERALDI, J. W. (Org.). 0 texto em sala de aula. 2. ed. Săo Paulo: Ática, 1999.

JAUSS, Hans Robert. A História da Literatura como provocaçâo à Teoria Literária. Sâo Paulo: Ática, 1994.

KLEIMAN, Ângela. Texto e leitor: aspectos cognitivos da leitura. 9. ed. Campinas: Pontes, 2004.

KLEIMAN, Ângela. Oficina de leitura - teoria e prática. 14. ed. Campinas: Pontes, 2012.

LEAL, Leiva de Figueiredo Viana. Leitura e formaçâo de professores. In: EVANGELISTA, Aracy Alves Martins; BRANDĂO, Heliana Maria Brina; MACHADO, Maria Zélia Versiani. (Orgs.). A escolarizaçáo da leitura literária: o jogo do livro infantil e juvenil. Belo Horizonte: Autêntica, 1999. p. 263-268.

MACHADO, Ana Maria. Bisa Bia, Bisa Bel. Săo Paulo: Salamandra, 1999.

NUNES, Sandra R. Sobre livros, leituras e literatura. FACOM. Săo Paulo, n. 19, $1^{\circ}$ sem, 2008, p. 52-56.

PAULINO, Graça; COSSON, Rildo. Letramento literário: para viver a literatura dentro e fora da escola. In: ZILBERMAN, Regina; RÖSING, Tania (Orgs.). Escola e leitura: velha crise; novas alternativas. Sâo Paulo: Global, 2011.

QUEIRÓS, Bartolomeu Campos de. 0 olho de vidro do meu avô. Săo Paulo: Salamandra, 2000.

RAMOS, F. B; PANOZZO, N.; ZANOLLA, T. Práticas de leitura em sala de aula. Revista Iberoamericana de Educación. Madrid: Organización de Estados Iberoamericanos para la Educación, la Ciencia y la Cultura (OEI), n 46/ fev. 2008. 
ROJO, Roxane. (Org.). Escola conectada: os multiletramentos e as TICs. Sáo Paulo: Parábola, 2013.

ROJO, Roxane. (Org.). Letramento escolar, oralidade e escrita em sala de aula: diferentes modalidades ou gêneros do discurso. In: SIGNORINI, I. (Org.). Investigando a relaçáo oral/escrito e as teorias do letramento. Campinas: Mercado de Letras, 2001. p. 51-74.

Recebido em janeiro de 2017.

Aceite em fevereiro de 2018. 